\title{
Revisiting neoliberalism in the oceans: Governmentality and the biopolitics of 'improvement' in the Irish and European fisheries
}

EPA: Economy and Space 2019, Vol. 5I(I) 156-177

(C) The Author(s) 2018

Article reuse guidelines: sagepub.com/journals-permissions DOI: $10.1|77 / 03085| 8 \times 18803 \mid 10$ journals.sagepub.com/home/epn

@SAGE

\author{
Patrick Bresnihan \\ Department of Geography, Trinity College Dublin, Dublin, Ireland
}

\begin{abstract}
Foucault's account of the emergence of biopolitics in the late 18th century helps frame the political economy of 'improvements' as an environmental project linked to the well-being of the population. Since the 1970s, biopolitical concerns have shifted towards non-human populations and the reproduction of natural resources and ecosystems. This has become evident in the European fisheries, where after decades of exploitation greatly intensified since the 1960s, the extractive demands of the fishing industry have caught up with the reproductive capacities of most commercially targeted fish stocks. This contradiction has given rise to a new political economy of 'improvements' that seeks to sustain the biological health of commercially targeted fish populations while maintaining an economically profitable fishing industry. Central to this transition is the active role that fishers are expected to play in sustainably managing the fish stocks they exploit while adapting to 'green' market opportunities. Tradeable quota systems, eco-accreditation schemes and community-based resource management have all emerged as managerial strategies for inciting the active participation of fishers in this 'common' project of sustainable development. Drawing on Foucault's perspective of governmentality, this paper argues that these strategies represent distinct but overlapping apparatuses of neoliberal governmentality that are representative of broader tendencies within environmental governance today.
\end{abstract}

\section{Keywords}

Biopolitics, neoliberalism, governmentality, environmental governance, fisheries

\footnotetext{
Corresponding author:

Patrick Bresnihan, Department of Geography, Trinity College Dublin, Dublin, Dublin 2, Ireland.

Email: bresnip@tcd.ie
} 


\section{Introduction}

In 2013, the reformed European Common Fisheries Policy (CFP) was launched with much fanfare and widespread praise; for the first time in its 30-year history the biological health of fish stocks was put at the centre of European fisheries management. Simon Coveney, acting fisheries minister under the Irish presidency of the EU, claimed: 'Whether you're an environmentalist or a member of an NGO who has been campaigning on this issue you can be very happy with the result. It's real, it's measurable, it's based on science ... it's very real' (Coveney, 2013; emphasis added). Coveney was referring to the goal of achieving maximum sustainable yield (MSY) in all fisheries by 2020. MSY is the highest number of fish that can be taken safely each year from a fishery while maintaining maximum productivity of the fish population. The scale of this task is vast - in some cases, it will involve a reduction in fishing mortality by $50 \%$. MSY is both a target and a starting point for fisheries management across Europe; it is a common goal around which scientists, fisheries managers, NGOs, consumers and fishers can work together to achieve 'real, measurable' changes in how the fisheries are exploited and managed.

Prioritizing the reproduction of fish populations (over intensifying extraction) at the EU level is both a response to, and provocation for, far-reaching and critical reflections on the structural failings of existing models of fisheries management (Bresnihan, 2016). Principal among these critiques is that top-down regulation of the fishing industry does not have the desired effects, and involves considerable costs to the member states and European Commission (See Jentoft \& McCay, 1996). Achieving MSY is thus understood to require greater collaboration between the fishing industry, fisheries managers and scientists. This is deemed necessary to improve the quality and quantity of data about the fisheries and to devise fisheries-specific programmes that are workable and produce measurable results in terms of reducing the levels of fish extraction. Commissioner Damanaki has articulated this explicitly in terms of devolving managerial tasks 'down' to the fisheries: 'So, we need to enhance the aspect of de-centralized decision-making. Issues that are merely technical do not belong to the political level' (Damanaki, 2011b: 2). She concludes that 'instead of establishing rules about how to fish, the rules focus on the outcome and the more detailed implementation decisions would be left to the industry' (Damanaki, 2011b: 11-12). Fishers are now no longer articulated as passive subjects of distant management and regulation, but 'active' participants in the management of fish stocks. The path towards the 'sustainable' fisheries of the future does not therefore simply involve the exclusion of fishers. Instead, it demands new forms of inclusion that reshape how fishers conduct their activity, relate to the marine environment and to global seafood markets.

Since the 1990s, critical scholars have documented and analysed the different forms that these liberalizing strategies of fisheries management have been taking around the world. The advent of market-based transferable quota systems in large commercial fisheries in North America, New Zealand and Norway has undoubtedly garnered most attention (Mansfield, 2004; McCormack, 2017). Akin to emissions trading schemes in the field of climate governance, tradeable quota schemes represent a clear example of neoliberal environmental policy-making and the modern-day enclosure of the ocean commons (Dalla Costa and Chilese, 2014; Pinkerton and Davis, 2015). If transferable quota systems are a clear example of neoliberal policy-making (using the market to allocate resources more efficiently), how do they compare to eco-accreditation schemes that seek to reward fishers for sustainably caught fish, or community-based management approaches implemented in small-scale fisheries? Quota trading systems, eco-accreditation schemes and community-based resource management have all been analysed (separately) in the literature as forms of neoliberal 
environmental governance (Bresnihan, 2017; Foley and McCay, 2014; Mansfield, 2004). But what makes them at once distinctly neoliberal and yet also distinct from one another?

Becky Mansfield's incisive and nuanced analysis of the history of neoliberal economic analysis within fisheries management since the 1950s has gone a long way towards addressing this question (Mansfield, 2004, 2007). In her article, "Neoliberalism in the oceans: "rationalization," property rights, and the commons question' (2004), she argues that the 'problem of property' has been at the heart of fisheries management since the 1950s, thereby orienting fisheries management around the central question of property rights. This is the 'tragedy of the commons' thesis in action and Mansfield argues that it is this liberal problematic that continues to lie at the heart of neoliberal strategies to 'rationalize' the fisheries; even where 'common property regimes' have challenged the narrow focus of classical private property regimes, the assumed need for some form of property rights framework capable of harnessing and regulating the profit motive of individuals can persist. ${ }^{1}$

This paper revisits Mansfield's article and the wider body of literature on neoliberal environmental governance that it is situated within (Bakker, 2010; Heynen and Robbins, 2005; McCarthy and Prudham, 2004) through an empirical examination of recent and divergent forms of (neoliberal) management in the Irish and European fisheries. The fisheries have proven a particularly rich empirical site for exploring the extension and ambiguities of neoliberal governance. As Mansfield and others have argued, this is in part due to the long history of neoclassical economic analysis within fisheries management (Pinkerton and Davis, 2015). Rather than emphasizing continuity over this period, however, I argue that it is the ongoing failure to address the problem of overfishing that has galvanized fisheries managers, scientists, policy-makers, environmental NGOs and even fishers themselves, to design novel techniques and technologies of governance (see also Bavington, 2010). This paper elaborates on this claim by drawing on and contributing to Michel Foucault's work on biopolitics, liberalism and governmentality, terms that I discuss in more detail in the next section.

In the following sections I turn to the Irish and European fisheries to outline three distinct apparatuses of governmentality that seek to 'better' deliver the generic goals of improved reproduction of fish stocks and socioeconomic viability for fishers. First, I examine the recent decision to introduce a ban on discarding across European fisheries and, relatedly, the growing support for individual transferable quotas (ITQs). Second, I discuss the Environmental Management System (EMS) introduced in Ireland as part of an effort to encourage fishers and fisheries to achieve green accreditation for their seafood. Third, I examine an attempt to institutionalize community-based management in the Irish lobster and inshore fisheries. These three approaches share a common liberal critique of 'top-down' management strategies of the past. These strategies are perceived as limited due to their inability to account for the complex realities and interactions between the marine environment, the market and the individual motivations and behaviours of fishers. What distinguishes these three apparatuses of governmentality, then, are not specific technologies or forms of property, but different understandings and configurations of these bioeconomic 'natures'.

The paper draws on research examining transformations in the governance of the Irish and European fisheries sector undertaken between 2007 and 2014 (see Bresnihan, 2016). Alongside analysis of policies and reports dating back to the 1990s, I carried out 16 months of fieldwork based in Castletownbere, a commercial fishing port in the south-west of Ireland, between 2008 and 2010. This fieldwork included meetings and interviews in the offices and research centres of relevant national departments and state agencies. I undertook 
25 semi-structured interviews with scientists, fisheries managers and policy-makers in Ireland, as well as interviewing and going to sea with 15 inshore and offshore fishers.

\section{Neoliberalism, governmentality and the biopolitics of 'improvement'}

Empirically informed analysis of neoliberal environmental governance has been particularly rich in the scholarship on contemporary fisheries management. The work of Becky Mansfield is particularly instructive in this regard $(2004,2007)$. She traces the origins of neoliberal approaches to fisheries management back to the 1950s and the work of fisheries economists like Scott Gordon, who asserted that '[t]he fish in the sea are valueless to the fisherman, because there is no assurance that they will be there for him tomorrow if they are left behind today' (Gordon, 1954: 125; see also Bavington, 2010). In Mansfield's analysis, the persistence and continuity of the 'tragedy of the commons' narrative provides a common point of departure for different neoliberal property regimes (private, state and community) that all seek to regulate the economic self-interest of individual fishers through the profit incentive. In this way, Mansfield makes a distinction between common property regimes that reproduce neoliberal assumptions and seek to harness market rationalities to resolve problems of overfishing, and those that foreground issues of social justice, equitable access and social protection from the market (Mansfield, 2007).

As well as aligning neoliberalism closely with property regimes that harness individual profit motives, Mansfield also discusses the distinction between the ideological claims of neoliberalism and its practical implementation. Making a point that intersects with much of the work on neoliberalism (Brenner and Theodore, 2002; Kingfisher and Maskovsky 2008; Larner, 2003; Rutherford, 2007), Mansfield writes: '[r]eal neoliberalism is not an unchanging and all-powerful force, but instead is a political project that incorporates, responds to, and shapes geographical, historical, sectoral, and even ecological variation' (2004a: 580). In her discussion of privatization of the North Pacific pollock fishery (through the implementation of individual tradeable fishing quotas), she draws on the Polanyian concept of contradiction to discuss how the so-called 'natural' market requires state intervention.

Mansfield's distinction between neoliberalism (privatization, profit motive, market penetration) and alternatives to neoliberalism (equitable access, social norms, market protections), and her critique of neoliberal assumptions about the 'free' and 'natural' market (free from state involvement) are common themes in the critical scholarship on neoliberalism and the fisheries. Critics of neoliberal fisheries management have tended to focus on and challenge the reductive, 'naturalized' depiction of fishers as profit-motivated economic agents, the negative social and economic impacts of privatization and the central role of the state in engineering such outcomes despite neoliberal opposition to state intervention (Pinkerton and Davis, 2015; St. Martin, 2007). Often aligned with a critique of capitalist accumulation, the literature also tends to identify how the extension of exclusive property rights allows for the reproduction of capital, even going so far as to suggest that neoliberal policies are implemented in service to capitalist interests (Pinkerton and Davis, 2015). Either implicitly or explicitly, then, contemporary forms of neoliberal fisheries management are considered a 'return' of classically liberal forms of enclosure and exclusion for many fishers from access to the commons.

That contemporary forms of liberalism mark a continuity with classical liberalism of the past is unarguable. What is less well elaborated in the literature on neoliberal environmental governance is what precisely characterizes this continuity and, conversely, what marks a discontinuity or novelty, if any. There is a large and diverse literature on the biopolitics of nature that has interrogated the nature of neoliberal natures within contemporary 
capitalism (see Leonardi, 2017; Nelson, 2015). Paul Rabinow's ground-breaking work in the early 1990s initially focused on the advent of biotechnologies and the new opportunities offered by informational, genetically coded bodies (Rabinow, 1996; see also Cooper, 2008). The work of Braun (2015), Pellizzoni (2011) and most recently Mansfield and Doyle (2017) has extended this critical inquiry into the relationship between new understandings of nature as lively, malleable and non-dualistic, with re-configurations of late liberal capitalism. Similarly, the work of Sullivan (2017), Robertson (2006) and Dempsey (2016) have demonstrated the co-constitutive relationships between ecosystem valuation and science and the financialization of nature within the expanding field of payments for ecosystem services. From a different perspective, Biermann and Anderson (2017) and Braverman (2015) have examined how the biopolitical shift towards non-human populations, specifically within biodiversity conservation, has involved new scientific categorizations of what species should live and die and how. Similarly, Reid (2013) identifies how generic concepts such as 'sustainable development' now indicate a fundamental shift in the focus of development, 'not simply from the economy to a wider understanding of human well-being, but from the development of human life to the non-human "life support systems" which peoples are said to depend on in order to live well and prosper' (Reid, 2013: 354).

This paper contributes to this expansive literature by examining three distinct forms of neoliberal governmentality that are at work in the management of the Irish and European fisheries. The focus of the paper is less on specific developments within fisheries science or the assembling of new forms of 'green' value, but on the characteristically liberal reformatting of responsibility that results from a critique of prescriptive politics and a commitment to economic reasoning. The rest of this section provides a brief explanation of how my understanding of governmentality helps to inform this analysis.

In the last of his 1976 lectures at the College de France and in his book The History of Sexuality, Foucault introduced the concept of biopower to describe a distinct form of power that seeks to administer, develop and foster life, 'a power bent on generating forces, making them grow, and ordering them, rather than one dedicated to impeding them, making them submit, or destroying them' (Foucault, 1998: 136). Foucault describes the environmental character of biopower in terms of the 'milieu' (Taylan, 2013). 'The milieu', he writes, 'is a set of natural givens - rivers, marshes, hills - and a set of artificial givens - an agglomeration of individuals, of houses, etcetera. The milieu is a certain number of combined, overall effects bearing on all who live in it' (Foucault, 2004: 21). Foucault goes on to explain that the milieu provides a novel field of intervention in which the target is not a body of individual legal subjects, or bodies capable of 'entrained performances', but a population, 'a multiplicity of individuals who are and fundamentally and essentially only exist biologically bound to the materiality within which they live' (Foucault, 2004: 21). The 'naturalness' of the population does not therefore refer to an ahistoric 'nature', but the complex and dynamic interaction of biophysical and economic phenomena, including desires and psychological inclinations. With this shift, nature is no longer understood to be 'external, holy and unchangeable', but rather consists of 'natural processes of life' that are amenable to measurement and regulation but not absolute direction (Lemke, 2011).

For Foucault, this represents a radical transformation in the operations of power and its relationship to knowledge. Now the sovereign must aim to govern based on the most accurate knowledge about the specific area in question, the conditions that pertain and the likely effects of different interventions. Equipped with this calculative knowledge, the sovereign can better assess the likely effects of specific interventions vis-à-vis particular goals. The total sum of interventions that arise from this political economic analysis (e.g. removing tariffs on grain, investing in drainage schemes, enclosing common lands, building road 
infrastructure) is what Foucault calls an 'apparatus of security', a way of 'arranging things so that, by connecting up with the very reality of these fluctuations, and by establishing a series of connections with other elements of reality, the phenomenon is gradually compensated for, checked, finally limited and, in the final degree, cancelled out, without it being prevented or losing any of its reality' (Foucault, 2004: 37).

This new relationship between calculative knowledge, truth and power forms the basis of a new liberal 'art of government' or governmentality, as Foucault calls it, that is not concerned with 'imposing law on men but of disposing of things: that is of employing tactics rather than laws, or even of using laws themselves as tactics - to arrange things in such a way that, through a certain number of means, such-and-such ends may be achieved' (Foucault, 1991: 95). ${ }^{2}$ Thus, crucially, from a governmentality perspective the question is not whether the state acts or not but rather how it acts and what justifies that action. ${ }^{3}$ As Thomas Lemke writes, the 'perspective of governmentality makes possible the development of a dynamic form of analysis that does not limit itself to stating the "retreat of politics" or the "domination of the market" but deciphers the so-called "end of politics" itself as a political programme' (Lemke, 2002: 10; emphasis added). Foucault's genealogy of liberal forms of government from the 18th century to the post-war 20th century was about trying to better understand how the state had become governmentalized, that is configured through economic rationalities rather than sovereign or disciplinary forms of power. What remains consistent within liberal thought is a commitment to remove politics from governmental practice - to corral all judgement into calculable rationalities. This impulse has been particularly evident in the fisheries, where sustained critique of management approaches has been driven by the failure to address overfishing and by the peculiar characteristics of the fisheries, including high degrees of uncertainty and complexity (Bavington, 2010). In response, calls to bypass top-down state strategies, develop better scientific models, and involve fishers directly in co-design and management of the fisheries have proliferated. In the following three sections I outline three distinct forms that neoliberal governmentality in the Irish and European the fisheries is taking.

\section{Liberal 'nature' and the logic of exchange}

'Discarding' refers to the practice of throwing unwanted fish overboard at sea because they are undersized, non-commercial (or less commercially valuable than other species) or the fisher has no quota for that species. The unpredictability of the sea and the mixed swimming patterns of many species of commercial fish mean that there will always be a quantity of unwanted fish in any catch. This is called the 'by-catch'. However, the quantity of discarded fish has increased dramatically over the past 30 years as fishing fleets have expanded their fishing capacity and target only the most profitable species. As early as 1975, the FAO estimated that one-third of all marine resources harvested were wasted in the post-harvest process. While some fish were lost during the wider distribution process, the bulk of the waste occurred at the point of capture, through the deliberate discarding of fish at sea. In the European fisheries, the problem of discards has become acute. While the figures are not accurate, it is supposed that in many fisheries discards are occurring at high levels, with mixed fisheries estimated to have a discard rate of anywhere between $20 \%$ and $60 \%$ (Commission for Environmental Cooperation, 2011a).

In the recent reform of the CFP (2013), the EU took the significant decision to implement a ban on all discards by 2019 through the introduction of the landing obligation (Commission for Environmental Cooperation, 2011a). At first sight the introduction and enforcement of a discard ban appears as a continuation (even extension) of a top-down 
approach to fisheries management, a regulatory directive that draws a clear line around what is allowed and what is not. Further examination, however, situates this legislative intervention within a longer and wider set of debates and arguments that are characteristically liberal.

In 2007, a report was published that was sponsored by the European Commission 'as part of an internal process of reflection' (Sissenwine and Symes, 2007). The report emphasizes the weakness of the existing quota system, which relies on annual thresholds being set according to inaccurate data. The emphasis on policing inflexible and inaccurate quotas has given rise to a bureaucratic, top-down control regime that the authors describe as 'archaic'. They write: 'It is clear that the CFP suffers a serious image problem. The Commission is seen as "regulator and enforcer" rather than as "facilitator or enabler," authoritarian and elitist in its unquestioning adherence to conventional fisheries science (stock assessments) and remote, unresponsive and bureaucratic in its relation with the industry' (Sissenwine and Symes, 2007: 50). Sissenwine and Symes conclude the report by calling for a fundamental reorientation of the CFP. If sustainable development of the fisheries is to move from a vague policy ambition to a practical reality, the authors argue, policy-makers must recognize and accept that the causes of overfishing consist of real economic motivations and behaviours which interact with the uncertain ecological patterns of different fish stocks. These realities are not going to disappear by simply increasing regulation and policing. The report advises the Commission to concentrate on measures that account for these bio-economic realities, such as a ban on discards, and the introduction of rights-based access to the fisheries.

This report was one of many publications and statements calling for a ban on discards in the 2012 reform of the CFP. Significantly, though, the report clearly articulates how support for a strong legislative act (discard ban) can be consistent with a liberal critique of 'topdown' management. This is because the rationale for the ban on discards explicitly addresses the economic behaviour and self-interest of fishers. As long as discarding was allowed, fishers could make calculated decisions about their catch after the point of capture and thus not have to worry too much about adopting more environmentally efficient but costly fishing equipment and new techniques. The ban on discards effectively takes this capacity for decision-making away from fishers, shifting it instead to the point of capture itself. As the Commission stated in 2011: 'It [the discard ban] will be a driver to avoid unwanted catches and will deliver a level playing field to change the fishing strategies of fishermen' (Commission for Environmental Cooperation, 2011c: 1).

The EU Commission has stated that under the discard ban, if fishers land commercial fish stocks in excess of their available quota, then they will remain subject to the normal penalties for overfishing. This puts considerable pressure on fishers to adopt more selective fishing practices and to collaborate with one another and with scientists to avoid the almost certain loss of fishing opportunities, financial penalties and/or criminal prosecution. ${ }^{4}$ These initiatives will not, however, be able to ensure that the number of fish that are caught (and landed) matches the allocated quota. Improved knowledge of fishing behaviour, distribution and swimming patterns as well as the design of more selective gear and fishing practices will account for some of the uncertainty inherent to fishing, but it will not eliminate it. In response, the recent CFP (2013) has also stated that some form of individual transferable quota (ITQ) system represents a pragmatic policy response to the mismatch between available quota and the quantities of fish that continue to be caught and landed. As with the ban on discards, the policy is designed to operate by incentivizing fishers to be more selective in their fishing (to avoid having to buy an increased quota) and by allowing less viable fishers to exit the fishery and sell their quota to more efficient operators. 
In the current CFP (2013), transferable quotas have been supported as a policy instrument but not made mandatory for member states; arguments for and against the introduction of ITQs continue. ${ }^{5}$ But the support for such schemes now should be understood within the context of protracted (and strongly criticized) efforts to prevent discarding in the past while enforcing quotas as a means of achieving MSY. While the effects of transferable quotas may well be the aggregation of fishing resources into the hands of larger, more profitable fishing operations, it is not these interests that have been pushing for transferable quotas. $^{6}$ The arguments for the ban on discards and the introduction of transferable quotas arise in the context of critical reflections on the failures of models of 'top-down' fisheries management and a desire to design policy interventions that take account of, rather than deny, the biological and economic 'nature' of the fisheries. This distinctly liberal reasoning bears close resemblance to Foucault's discussion of the emergence of liberal political economy in the 18th century in response to the problem of grain scarcity.

In the 18th century, grain scarcity was a constant concern for the authorities in France because the lack of grain in towns often precipitated rioting and social disorder. Before the 1750 s the dominant response to this problem had been a policy of 'anti-scarcity'. In other words, the authorities sought to prevent grain scarcity by directly intervening in the grain markets, prohibiting the withholding of grain by forcing peasant producers to supply the market even if they made a loss. Despite these costly efforts, the problem of grain scarcity continued. It was this failure of government policies to effectively manage the problem that provoked new ways of thinking about the problem of grain scarcity and the proper basis for good government.

Foucault focuses his discussion on a text from the 1760s, Louis-Paul Abeille's Lettre d'un négociant sur la nature du commerce des grains. In his text, Abeille begins by questioning the basis of 'anti-scarcity' policies. The problem, Abeille argues, is that scarcity is framed as something 'bad' or 'unnatural' that must be stopped. This results in a considerable waste of resources spent on prevention and regulation by the state. It also results in ruin for peasants who are essentially punished to ensure low grain prices. In the final analysis, the policies of the authorities were always going to fail if their sole objective was to prevent scarcity. For Abeille, the roots of ineffective government were policies derived from what was thought desirable rather than from a careful analysis of what was happening. Rather than trying to prevent scarcity, therefore, policy-makers should begin by accepting the 'reality' of scarcity, its existence as a phenomenon made up of real underlying causes.

The consequences of this analysis are that scarcity itself is no longer the primary object of analysis or intervention. Rather, such events are understood to be the result of a much wider set of social, economic and environmental factors - the dynamic, aleatory events that make up the 'milieu', including the biophysical reality of the grain itself, the economic motivations of the grain producer and the broader economic context, with its fluctuations and dynamics unfolding at regional, national and global levels. Beginning with these different elements and the ways they interact through the market entails a radical shift in the knowledge and practice of government. It means 'trying to grasp them (economic behavior, the production of grain) at the level of their nature, or let's say - this word not having the meaning we now give it-grasping them at the level of their effective reality' (Foucault, 2004: 47; emphasis added).

In this classical liberal analysis, bio-economic 'nature' thus becomes a limit on power, something that must be acknowledged and obeyed if government is to ensure the ongoing security and well-being of the population. Paradoxically, however, it is this apparent weakening of sovereign power over the population that produces a more pervasive, dominant 
form of power through its claims to only act in accordance with what is 'natural', that is what pertains in the bio-economic operations of the population. ${ }^{7}$ As Foucault writes,

the principal of the necessary freedom of economic agents can coincide with the existence of a sovereign who is all the more despotic and unrestrained by traditions, customs, rules, and fundamental laws as his only law is that of evidence, of a well-formed, well-constructed knowledge which he will share with the economic agents (Foucault, 2008: 285).

This line of reasoning establishes a powerful and productive relationship between the freedom (and responsibility) of the individual to conduct themselves 'rationally' and the achievement of the overall goals of economic productivity, or in the case of the fisheries, sustainable fish stocks. Those who are unable or unwilling to fish in accordance with the reproductive cycle of fish populations (and demands of the market) can thus be penalized because they are abusing what is 'common'. The force of this argument is articulated through the escalating surveillance and policing of the fisheries, culminating in Commissioner Damanaki's recent commitment to ensure a 'zero tolerance' policy towards illegal fishing (Commission for Environmental Cooperation, 2011b).

What starts to become visible in the convergence of the ban on discards and the possible introduction of an ITQ system is the Janus-faced nature of liberal forms of government: on one side, the promise of individual freedom, and on the other an economic rationality that is all the more dominant because it claims to act in accordance with what is 'real', namely the measurable, biological health of the fish stocks and the self-interested behaviour of fishers. There are clear parallels between the strategies and instruments employed to 'liberate' fishers from the imposition of economic and regulatory pressures (inflexible quota limits) and classical liberal forms of laissez-faire policy-making. This is important to keep in mind because recent reforms of European fisheries management have also been characterized by a different formulation of the problem of overfishing, the economic nature of fishers, and the proper role of the market in addressing the twin challenges of depleting fish stocks and the pressures of a competitive global seafood market.

\section{Eco-accreditation and the making of the environmental entrepreneur}

The EMS was launched by Bord Iaschaigh Mhara (BIM), the state agency with responsibility for developing the Irish fishing industry, in 2010. The EMS is a voluntary auditing scheme designed to help Irish fishers to minimize their impact on the marine environment. It does this by allowing individual fishers to record and document different aspects of their impact on the marine environment. ${ }^{8}$ The motivation for fishers is that this 'book of good deeds ${ }^{9}$ will enable them to actively engage and negotiate with state and non-state actors, whether in terms of applying for international eco-accreditation or in demonstrating they are following the regulations.

There are no minimum or maximum requirements attached to the EMS; everyone is encouraged to complete as little or as much of it as they want. This flexibility is assumed to be one of its advantages. Jean O'Sullivan, ${ }^{10}$ who spearheads the project for BIM, enthusiastically endorsed the system when I spoke with her, pointing to the benefits of 'working at the smallest unit of management'. ${ }^{11}$ O'Sullivan emphasized the value of a tool like the EMS for providing the space for individuals like this 'to take the initiative'. This contrasts with previous models of environmental management, she said, that tend to prescribe what should be done within relatively rigid regulatory frameworks. The EMS attempts to bridge the gap 
between achieving the 'common' goals of marine conservation and enabling fishers to be creative and adaptive within their own locality and environment.

Although the EMS itself may not be prescriptive, it has emerged in response to an economic and regulatory context that is prescribing new limits and demands on fishers. The main incentive and motivation for the EMS is that it will help fishers secure accreditation for their fish, which in turn will allow them to differentiate their catch in the market and command a higher price. The liberalization of the global seafood market over the past 30 years has meant fishers around the world have been competing in terms of price. The introduction of eco-labels is designed to punctuate this 'level playing field' through the artificial differentiation of products: the creation of secondary markets in 'environmental' seafood (Guthman, 2007). By pitting fishers against their 'less sustainable' competitors at home and abroad, the EMS attempts to resolve economic and environmental problems besetting the fisheries sector by extending and transforming the market rather than regulating it.

While there are different accreditation schemes, including national ones, the 'gold standard' of environmental accreditation in the fisheries is the Marine Stewardship Council (MSC) accreditation. ${ }^{12}$ The MSC assesses the sustainability of individual fisheries based on 31 performance indicators principally related to the biological sustainability of the fish stocks being accredited (Marine Stewardship Council, 2011). Once a group of fishers or a fishing association (including of buyers) have identified themselves and the fishery they wish to gain accreditation for, a 'fishery client' must make a formal application to the MSC for assessment. The 'fishery client' can be a government agency or fishing industry association and is required to identify an independent 'third-party' certifier accredited to carry out assessments for fisheries against MSC standards. These independent certifiers are themselves certified by Accreditation Services International (ASI), the sole provider of accreditation services to the MSC. The authorized independent certifier is paid a fee by the applicant fishery to carry out the assessment and issue certification. To speed up the assessment process (which is estimated to take at least 17 months), applicants are encouraged to have as much biological and economic information as they can for the assessment team. This is where the EMS comes in: as a record of individual fishing activities it can provide valuable information for the certifying body.

Recent literature has identified eco-labels and environmental accreditation standards as novel forms of neoliberal environmental governance that reflect the assumptions and goals of ecological modernization (Foley, 2012; Foley and Hébert, 2013; Guthman, 2007; Klooster, 2010; Ponte and Cheyns, 2013). Eco-labels are understood to incite desirable types of behaviour (environmental 'stewardship') at the same time as they open new areas of 'green' market value that do not rely on intensified levels of resource extraction. What is not so clear is why and how a technology like the eco-label, and the wider governmental apparatus involved, is different from other market-oriented strategies, such as the ITQs outlined above.

In his lecture series in 1978-1979, Foucault argued that the development of neoliberal thought in the 20th century did not just represent a return of classical liberalism (free markets, private property, laissez-faire policies), but a transformation in liberal thought and forms of governing. According to Foucault, the principle critique of classical liberalism by 20th-century neoliberal thinkers was the 'naive' formulation of the market economy as a 'natural' sphere of exchange operating at the limit of the state. For the post-war neoliberal thinkers, this 'naivety' stemmed from the liberal assumption that the market was principally a site of exchange. In this account, the function of the market was as a medium, facilitating the exchange of goods and services and the balancing of supply and demand through the 
price mechanism: if the price of fish quotas for certain species rise due to reduced supply, then fishers will respond by targeting other species, and so on.

In response, Foucault shows how post-war neoliberal thinkers reconceptualized the market not as a site of exchange but as a site of competition; it is competition between individuals that provides the necessary and continuous friction capable of mobilizing society towards desirable goals (Amable, 2011; Dardot and Laval, 2013). At the same time, competition is not as the liberals understood exchange, a kind of natural interplay between economic subjects mediated by the price mechanism. If the real function of the market is competition, then this is something that must be cultivated and maintained, not presumed. Re-framing the market as something artificial undoes a further assumption of classical liberalism: the distinction between the market economy and the state, a distinction that had to be rigidly maintained within classical liberalism. If the market depends on competition, and competition is not a natural state, then this distinction does not hold - there is no 'natural' limit on the state's authority. Instead, the state is enjoined to play an interventionist role, not only in the 'economy', but in the extension of competitive relations to areas of society previously thought to be outside the economy. Rather than maintaining liberalism's level playing field, the neoliberal state must intervene to cultivate artificial forms of inequality that encourage and incite certain forms of behaviour, which in turn achieve a wide range of social, environmental and economic goals. The most important innovation of neoliberal thought in the 20th century, then, is the denaturalization of the so-called 'free' market that operates at the limit of the state (Leonardi, 2017); neoliberal governmentality opens a more extensive and interventionist role for government through the deliberate cultivation of (competitive) economic rationalities and strategies.

Following Foucault's analysis of neoliberalism, a considerable body of literature has documented the rise of both an 'enterprise culture' and a 'culture of responsibility' across different sectors of civil society (Burchell, 1996; Rabinow and Rose, 2006; Read, 2009). In the fields of work, healthcare and education, individuals are increasingly 'empowered' to take on responsibility for their future, 'to be understood and targeted as an active participant in the activity of work, not merely as an instrument of production but as a person: a human being realizing his or her self through work' (Rose and Miller, 1995: 430). Instead of shaping individual behaviour through direct material incentives and disincentives (ban on discards, price), neoliberal technologies incite individuals to work on their own performance through comparison with others, enabled through the proliferation of auditing metrics and technologies, such as the EMS. In the case of the EMS and the MSC accreditation, the intention is that individual fishers will not only engage in self-monitoring but also in efforts to translate this record of 'good' performance into new 'sustainability networks', such as international accreditation schemes (Ponte and Cheyns, 2013).

A hierarchy of winners and losers is explicitly programmed into a technology like the ecolabel; it is through the logic of differentiation that the most active individuals will be rewarded, and spurred on to do more. Thus, while the eco-label remains wedded to the functioning of the market as a means of educating behaviour, it is not through the logic of free exchange but rather of artificial competition that this is directed. To incite this competition, new ways of measuring, benchmarking and comparing the environmental credentials of seafood are required (Bresnihan, 2016). What is being measured, the technologies for measuring it, and the institutional arrangements that frame it, is thus different from that which is targeted through the discard ban and ITQ system.

This helps us to see how transformations in liberal thought represent powerful new currents of governmentality that become crystallized in the figure of the neoliberal 'enterprising' subject. The state-led EMS programme and the globally authoritative 
eco-accreditation schemes it aims for conspire to foster this entrepreneurial relationship through the promise of greater market access and financial reward. But the failure of such schemes to take off, particularly in small-scale fisheries which do not have the financial or informational resources to become accredited, has led to criticism (Marine Stewardship Council, 2010). Alongside the perceived limitations and negative effects of liberal ITQ systems and, to a lesser extent, the inaccessible networks of eco-accreditation, a third form of fisheries governance has developed over the past 30 years: community-based fisheries management.

\section{The neoliberal commons}

Since the late 1980s, there has been growing concern about the state of Ireland's lobster stocks and, more specifically, the absence of any significant management framework to regulate the lobster fisheries. ${ }^{13}$ In 1994, regional lobster fishing associations and cooperatives first formed around Ireland under the umbrella of the Irish Lobster Association (ILA). Inspired by the example of the Maine lobster fisheries and mobilized by the partial success of recent collective actions, several groups of inshore fishers in Ireland, mostly from the south coast, began pushing for the introduction of statutory regulations on fishing and some form of community-managed lobster fisheries.

From the beginning, fisheries managers, scientists and the associations of inshore fishers involved in efforts to regulate the lobster fisheries were unified in wanting to avoid any system of individual transferable rights or quotas. This was primarily because of the risk of 'aggregation' (concentration of the resource in few hands). As John Carney, the lead fisheries scientist involved in developing a co-managed model for the inshore fisheries, summarized: ' $[t]$ he one thing we're saying with the lobster is you can have an exclusive right, but not a transferable right - that's the difference with ITQ. That will enable the long-term view without creating this great cost for the next generation who want to get into the fishery'. ${ }^{14}$ This socially oriented commitment to avoiding ITQs was also combined with a belief that community-based fisheries management provided other benefits, such as collective responsibility and action, that would contribute to the overall aim of achieving sustainable fisheries.

In 2008, BIM published a consultation document for the lobster fisheries. Managing Access to the Irish Lobster Fishery provided the basic outline for a management plan for the lobster fishery and offered a blueprint for the management of other inshore fish species. The significance of the proposed plan was that for the first time a form of regulated access to the lobster fishery would be legislated for and enforced by the state. Fishers who currently had a licence to fish for lobster would be issued an authorization that would allow them to fish for lobster within their zone. There was a limit placed on the number of authorizations issued. These authorizations could not be bought or sold and thus did not function as a tradeable right of access. There were no criteria set for how many pots a fisher could set, but the expectation was that the security promised by the limited entry for fishers and the scale of the fishing zones would foster collaboration and collective decision-making in the management of the fish stocks.

One of the most important texts within the tradition of institutionalized collection action is Elinor Ostrom's (1990) Governing the Commons. In this seminal text, Ostrom, an economist, makes it clear where her motivation for researching the rules and institutions of collective action lies: the power of certain dominant narratives for explaining the causes of resource degradation and the limited choice of management strategies that arise as a result. For Ostrom and her colleagues, the 'inevitability' of Hardin's 'tragedy of the commons' 
thesis was based on the inaccurate portrayal of resource users as 'helpless individuals caught into an inexorable process of destroying their own resources' (Ostrom, 2008: 8). By representing individual resource users as deliberative agents capable of arriving at mutually agreed solutions to resource-based problems, a whole new field of inquiry into institutions for collective action was generated (Agrawal, 2006; Forsyth and Johnson, 2014). ${ }^{15}$ The focus of this work has tended to be on real-world settings, where rules, norms and knowledge practices governing resource use and access have proven successful, often for centuries. As Forsyth and Johnson (2014) argue, this 'positive, rather than normative' approach to institutions and their role in shaping social, political and economic life has been central to the re-working of institutional approaches to the commons. ${ }^{16}$ The emphasis on empirical case studies, a resistance to 'one-size-fits-all' solutions and the goal of designing institutional models that work 'on the ground' in often messy, diverse contexts has appealed to resource managers frustrated with the apparent inefficacy of existing institutional models, particularly in a context of worsening problems of environmental degradation (McCay and Acheson, 1990; Agrawal, 2003).

Underlying critiques of existing models of resource management is a critique of the forms of knowledge and analysis that guided such models, particularly the capacity of top-down, scientific expertise to achieve effective management in diverse, complex and dynamic socioecological contexts (Berkes and Folke, 1998). The foregrounding of complexity and unpredictability in relation to environmental management has encouraged managerial solutions that target the situated, responsive and collective capacities of local communities. This historic shift is important for understanding changes within environmental governance, particularly the valorization of local forms of knowledge and resilience in a context of growing ecological risk and complexity (Joseph, 2013; Vardy and Smith, 2017). This is well-illustrated in the case of the Irish inshore fisheries.

The fisheries managers, scientists and representatives of the inshore fishers involved in designing a management plan for the inshore fisheries wanted, explicitly, to avoid the 'negative social and economic effects' associated with a system of individual tradeable quotas. At the same time, they wanted to ensure some form of regulated access, which required the carving out of territories and the allocation of authorizations. The difficulty was that the geographic specificity of the lobster populations and fisheries meant that greater degrees of flexibility and participation on the part of the fishers would be required. As one of the BIM consultation documents put it, the co-managed approach is a 'form of experimental adaptive management [that] is highly suited to stocks which are structured geographically, and where the relative effects of fishing and environment on catch rates are unknown' (Tully, 2004: 4; emphasis added). Engaging and enabling local fishers to participate directly in the management of their own fisheries was understood to be a vital means of accounting for such uncertainty.

Much of the data that informed the setting of the territorial boundaries was generated through records kept by fishers on where and what they caught, as well as through nationwide consultations with representatives from local inshore fisheries advisory committees set up as part of the process. For Carney, the fisheries managers and the inshore fishers actively involved in consultations on the fisheries management plan, these data were necessary to determine the most appropriate scale for the territorial units that would form the basis of the management plan. As Carney put it: "to establish at what scale will the fishermen and the lobsters be enabled to organize and engage in productive relations with each other?'. ${ }^{17}$ Significantly, the ongoing participation of fishers in observing, monitoring and making management decisions about the fish stocks they targeted was not just about collecting new data, but about moving beyond the traditional model of fisheries science itself 
(see Acheson, 2003). For example, Carney made clear that in the inshore fisheries there was now a move away from predictive models towards the use of 'simple indicators' capable of tracing general patterns and tendencies over time. This allows fisheries scientists, managers and fishers to come together and identify whether certain actions are working vis-à-vis these simple indicators. This managerial approach describes a process rather than a singular regulatory event or instrument for managing the fisheries.

Support for community-based resource management in a context of neoliberal restructuring, specifically the devolution of responsibility from more centralized state institutions to individual citizens and communities, has provoked critical scholars to question the extent to which localized, commons-based forms of organization provide an alternative or an extension of neoliberal rationalities (Bakker, 2005; Birkenholtz, 2009; Bresnihan, 2017; De Angelis, 2013). The work of anthropologists examining the reconfiguration of state power in the management of natural resources since the 1990s provides a particularly useful application of the governmentality approach for understanding the extension and workings of liberal biopower (Agrawal, 2003; Brosius et al., 2005). Understood from this perspective, the enrolling of localized, collective forms of self-governance is neither about the withdrawal of the state nor the advance of the market, but 'an opportunity to rearrange the ways in which rule is accomplished, while also offering communities an opportunity to realign their position within (but not outside) the state system' (Li, 2002: 278).

What persists through co-managed approaches to fisheries management is a commitment to establishing an economic rationale for good governance, one that relies on the collection, comparison and institutionalization of data reflecting the operations of specific lobster stocks, territorial ecosystems, collectives of fishers and market prices. In other words, not challenging market forces or promoting a desirable alternative, but working more closely with what can be measured, and made amenable, to resolve socio-ecological contradictions. What $i$ novel is the explicit aim of working with and fostering the productive capacities for cooperation between individuals and their environment in order to better achieve sustainability goals. In other words, the institutional approach to the commons does not deny the 'free-rider' problem, but suggests that there are better ways of resolving it (Forsyth and Johnson, 2014). Rather than 'coercing' the economic individual through some form of stateenforced private property regime, or fostering competition through eco-accreditation, this approach seeks to craft context-specific institutions in which specific groups of individuals are enabled to work together to achieve beneficial outcomes (Agrawal, 2003; Forsyth and Johnson, 2014).

\section{Conclusion}

While the co-management plan for the lobster fisheries was put out to consultation in 2008, nothing was implemented. In 2012, the situation changed as an unexpected impetus for the co-management plans arose. In response to the threat of fines from the European Commission for failing to adequately classify or protect several important areas of biodiversity conservation, previously peripheral areas along the Irish coast suddenly became a priority for the state. The reforms mandated assessments of all licensed activities, including fishing, taking place within these designated areas to make sure they did not adversely affect key species. The need to demonstrate that fishing was being carried out sustainably gave a new impetus to the lobster co-management framework. One of the fisheries managers who had been driving the plans said that lobster fishers were suddenly 'willing to do anything to be involved' because of the threat of the European directives (and potential exclusion from the fisheries entirely). While the fisheries manager expressed disappointment that it took this 
kind of regulatory pressure to galvanize fishers and the Irish government into acting on the management plan, she welcomed the positive effects it was having.

In the end, the threat of European sanctions for non-compliance did not materialize, and the plans to manage access to the lobster fishery were put on hold. In a subsequent email exchange in 2014, the lead fishery manager said that the management plan had come to a standstill again partly because of government 'foot-dragging', but mostly because of the 'short-term' attitude and lack of support from lobster fishers who were fearful that the new management plan would affect the value of their tonnage. ${ }^{18}$ But there were new opportunities arising. The lead fisheries manager involved with the EMS imitative described a recent development with crab fishers on the west coast. These fishers had approached BIM looking to gain environmental accreditation for their crab. For this to happen, the crab fishers have been encouraged to individually work on their own EMS, while at the same time working together to demarcate their fishery and the fishers involved in it. This appeared to be an example of how fishers taking the initiative to market their catch could drive plans for the co-management of the inshore fisheries, and vice versa. The point was that marketing opportunities like eco-labels could encourage fishers to work collectively by demonstrating that a biologically sustainable fishery could also be a profitable fishery. What do these unfolding developments demonstrate about both contemporary fisheries governance but also, more importantly, the logic and practice of neoliberal governmentality in a context of environmental governance?

First, the response from the fisheries managers to their frustrated efforts to implement a co-managed model demonstrates a centrally important relationship between failure and the reflexive art of governmentality. Through its commitment to working on what it assumes to exist (rational economic subjects, commodity markets, uncertain marine environments), rather than challenging these basic coordinates, the failure of a specific intervention can always be interpreted as resulting from a lack of adequate information, the wrong approach to consultation, or a misreading of individual motivations. Rather than resulting in the wholesale abandonment of these projects, this reflexivity invites new rounds of data collection, revised forms of engagement, and ultimately novel governmental interventions. This logic was perhaps best articulated by one fisheries manager involved in the design of the comanagement framework, who asserted: '[i]nternational experience tells us bottom up, bottom up, bottom up and not to force the process, just keep going back and back until you are driven demented by the whole process' (Smith, 2009). Ultimately, difficulties or failures arising from the ban on discards, the introduction of ITQs, eco-accreditation schemes, or the co-management plan are more likely to reinforce (rather than challenge) the 'will to improve' $(\mathrm{Li}, 2007)$ that aims to align the economic interests of individual fishers with the vagaries of a global seafood market and the unpredictable marine environments they work in. What should also be clear in this context is that as new 'opportunities' are devised and extended to fishers to demonstrate their sustainability within seafood markets, those who are unable or unwilling to engage with these technologies will become 'unsustainable'. Over time this protracted process of 'improvement', the tightening of economic and regulatory pressures, will exclude more fishers from the fisheries than any one-off regulatory event (e.g. privatization).

Second, analysing neoliberal environmental governance as a protracted 'will to improve' that orientates around a concern for the reproduction of natural resources and ecosystems provides a more critical perspective on the support of supposed 'alternatives' to neoliberalism. Representations of neoliberalism as a 'return' of classical liberalism, with a focus on property regimes and market instruments, can (and has) given rise to some scholars describing it as inflexible and reductive (Pinkerton and Davis, 2015; see also St. Martin, 
2007). Against these simplifications, small-scale fisheries are, for example, identified as potential points of resistance in terms of the contributions they make to public welfare, 'by promoting more economically-beneficial equality and adapting to climate change and recession' (Pinkerton and Davis, 2015: 310; see also Foley and Mather, 2016; Mather et al., 2017). The affirmation of 'positive' community-based economies against the 'negative' tendencies of neoliberalism extends beyond the fisheries (Gibson-Graham, 2008). While broadly supportive of the move to valorize alternative economies and socio-ecological relations, one of the insights that arises from a governmentality perspective is that neoliberal biopolitics is adaptive and inclusive, keen to identify and incorporate qualities and properties (including non-capitalist exchange and cooperation) towards the overall goals of manageable populations and a functioning capitalist economy. If we take neoliberal environmental governance to be characterized by the re-scaling of responsibility away from public institutions, the inclusion of difference, and the creative mobilizing of individual agency, then it is possible to understand the proliferation of local, community-based initiatives as consistent with rather than alternative to late liberal forms of power (Povinelli, 2011).

A third, related, argument made in this paper is that scholars of neoliberal environmental governance should be more sensitive to the distinctions between historic forms of liberal thought and practice and the novel forms it continues to take today. At the end of his lecture series given between 1978 and 1979, Foucault poses an invitation to current and future scholars: 'What should now be studied, therefore, is the way in which the specific problems of life and population have been posed within a technology of government which, although far from always having been liberal, since the end of the eighteenth century has been constantly haunted by the question of liberalism' (2008: 324; emphasis added). Foucault suggests here that the 'question of liberalism' is never settled, but emerges anew in response to specific problems of life and population. This is in contrast to a recent call by one leading scholar in the field that there is nothing new about neoliberalism (Lave, 2018). Her analysis arises from an understandable appreciation of (and concern for) the "on-the-ground consequences for people and ecosystems of so-called "neoliberal natures": enclosure, loss of livelihoods and sacrificing ecosystems to enable development' (Lave, 2018: 30). But what a governmentality perspective offers here is a means of better understanding how the ongoing violence of enclosure and exclusion is folded into a consistent but inventive logic of liberal 'improvement' that serves to justify and obscure such exclusions. Tania Li (2007) employs the concept of 'improvement' to better capture the more protracted process of governmental reflection and intervention that provides the context and conditions in which the exclusion of some from access to vital resources may come to not only make sense but even appear unavoidable. The governmental rationalities outlined above all share a positive desire to include fishers in the project of sustainable fisheries. This is not just empty rhetoric as evidenced by the fishers who have begun collecting data on their own fish stocks, or the 'winners' who have achieved MSC status. Behind these examples of pro-active fishers, however, is the knowledge that increasingly competitive, global seafood markets equates to a highly uncertain future in which making a livelihood from fishing will be extremely hard. As one fisherman summed up: 'We have to do something. We're at a standstill. It is survival of the fittest.' Without challenging the structural violence of a capitalist political economy in which fishing is embedded, the exclusion of fishers from the fisheries on the grounds of protecting fish stocks will continue to appear unavoidable. As this paper has demonstrated, the means through which exclusion is justified, or comes to make sense, in the case of the fisheries is not always spectacular or obvious. More often it is banal, protracted and partial. 
Paying critical attention to these processes, and connecting them with Marxian political economic analysis of enclosure and appropriation will continue to be important.

\section{Declaration of conflicting interests}

The author(s) declared no potential conflicts of interest with respect to the research, authorship and/or publication of this article.

\section{Funding}

The author(s) received no financial support for the research, authorship and/or publication of this article.

\section{Notes}

1. 'I contend that neoliberalism in the oceans centers specifically around concerns about property and the use of privatization to create markets for governing access to and use of ocean resources' (Mansfield, 2004: 314)

2. This understanding of governmentality as an ensemble of tactics, which may include laws (i.e. state regulation), runs against Robert Fletcher's recent argument for 'multiple governmentalities' that he categorizes as neoliberal, disciplinary, sovereign and truth. My reading of Foucault argues that governmentality has only ever been liberal, which is to say a mix of state and non-state actors, technologies and techniques, but always a mode of governing that operates on and through the individual, economic subject and economic rationalities.

3. Similarly, this speaks against a recent article by Robert Fletcher (2017) that has sought to encompass the literature on 'multiple governmentalities' within environmental governance. Fletcher sketches a typology of governmentalities that orientates around sovereign, disciplinary, neoliberal and spiritual forms of power. I disagree with this reading of Foucault's work which is a genealogy of liberal governmentality, that is how the modern state has become governmentalized. Thus, while different tactics and techniques may be used (including juridical and market-based instruments), the significance of a governmentality approach is that it rests on economic (rather than moral) rationalities and the shaping of individual conduct (individual as instrument, not target of power).

4. During my research, for example, in 2009 a marine scientist in Ireland's Marine Institute who is responsible for leading EU-wide 'industry-science' partnerships told me that over the past few years there had been a fundamental change in 'culture': 'fishermen are now realizing that historically, just by not giving us data it was a kind of protest, you're not allowed in here, you're not allowed onto our boats, is actually coming back to haunt them ... there is now a bit of a scramble with everyone now suddenly loving the scientist.'

5. In Ireland, for example, ITQs have not been implemented because of the potentially negative social and economic impacts it may have on a fishing industry that is still relatively undercapitalized, community-based and consisting of trawlers that are owner-operated (rather than the vertically integrated fishing companies in countries like Spain and the Netherlands).

6. Commissioner Damanaki has argued that ITQs should be seen less as property rights and more as user rights that grant access to a 'common' resource for those who are able to fish responsibly. She is confirming a position that has been made since at least 2009, when the reform process for the CFP was launched: 'so far the fishing industry has been given free access to a public resource and management costs have been largely incurred by taxpayers.... Those who exercise responsibility in a proper and effective manner should be the ones to enjoy the access to fish stocks' (Commission for Environmental Cooperation, 2009: 12; emphasis added). 
7. Foucault writes: 'You can see therefore that the principle of laissez-faire in the physiocrats, the principal of the necessary freedom of economic agents can coincide with the existence of a sovereign who is all the more despotic and unrestrained by traditions, customs, rules, and fundamental laws as his only law is that of evidence, of a well-formed, well-constructed knowledge which he will share with the economic agents' (Foucault, 2008: 285; emphasis added).

8. Physically, the EMS consists of a booklet, a little bigger than A4 paper, laid out in 14 chapters or sections covering every aspect of a fisherman's environmental, economic and community performance, including fuelling operations and maintenance, hygiene management, fishing practices, food safety and quality, waste management, occupational health and safety, communication and public perception and sustainable fisheries management and research.

9. J Carney, interview with the author, Galway, 12 August 2009.

10. The names of all respondents have been anonymized.

11. J O'Sullivan, interview with author, Dublin, 30 June 2009.

12. The MSC was established in 1997 by the multinational company Unilever and the international NGO World Wildlife Fund. It was one of the first worldwide certifying bodies, and was established to raise consumer concerns about declining fish stocks. Despite the existence of other seafood eco-labels, the MSC remains the dominant player in the field, giving it a near monopoly in the 'sustainable fish' market (Foley and Hébert, 2013; Gulbrandsen, 2009).

13. Historically, the inshore fisheries have been the social and economic mainstay of small coastal communities. The inshore sector describes a territorial area as well as a type of fishing: the inshore extends out six nautical miles from the national coast of each European member state and refers to vessels of less than $12 \mathrm{~m}$.

14. J Carney, interview with the author, Galway, 12 August 2009.

15. "The potential of this perspective has not been lost on scholars who explicitly position themselves within the tradition of liberal thought: at the core of Ostrom's work is the insight that many, though not all, of the free-rider and collective-good problems that are usually presented as requiring external regulation may be better addressed by relying on the ingenuity of those most affected by them to devise an appropriate set of rules. This is an insight that is close to the heart of the classical liberal tradition and which has prompted a new generation of scholars to catalogue cases where we observe the formation of rules without the exercise of external authority" (Pennington, 2012 : 40-41; my emphasis).

16. Governing the Commons, they write, was part of a highly influential series published and co-edited by James Alt and Douglas North, whose work on the institutional foundations of economic and political life was highly influential in the American social sciences (Forsyth and Johnson, 2014).

17. J Carney, interview with the author, Galway, 12 August 2009.

18. Tonnage represents the share of the quota allocated to a particular boat: the larger the tonnage, the higher proportion of the allocated quota a boat will receive. Tonnage can be sold between boats, but unlike tradeable quotas, the transfer of tonnage tends to be a one-time event, usually when a fisher leaves the fishery. In the absence of a decent pension, fishers commonly see tonnage as a capital asset that can be realized when they retire from fishing. The reason why polyvalent licence-holders in the inshore fisheries opposed any system of managed access to the lobster fishery was that any limits on who can come in and out of the fishing zones would effectively mean a reduced market for their tonnage.

\section{References}

Acheson JM (2003) Capturing the Commons: Devising Institutions to Manage the Maine Lobster Industry. Hanover, NH: University Press of New England.

Agrawal A (2003) Sustainable governance of common-pool resources: Context, methods, and politics. Annual Review of Anthropology 32(1): 243-262.

Agrawal A (2006) Environmentality: Technologies of Government and the Making of Subjects. Durham, NC: Duke University Press.

Amable B (2011) Morals and politics in the ideology of neo-liberalism. Socio-Economic Review 9(1): 3-30. 
Bakker KJ (2005) Neoliberalizing nature? Market environmentalism in water supply in England and Wales. Annals of the Association of American Geographers 95(3): 542-565.

Bakker KJ (2010) The limits of 'neoliberal natures': Debating green neoliberalism. Progress in Human Geography 34(6): 715-735.

Bavington D (2010) From hunting fish to managing populations: Fisheries science and the destruction of Newfoundland cod fisheries. Science as Culture 19(4): 509-528.

Berkes F, and C Folke, editors. 1998. Linking Social and Ecological Systems: Management Practices and Social Mechanisms for Building Resilience. Cambridge University Press, New York.

Biermann C and Anderson RM (2017) Conservation, biopolitics, and the governance of life and death. Geography Compass 11: e12329.

Birkenholtz T (2009) Groundwater governmentality: Hegemony and technologies of resistance in Rajasthan's (India) groundwater governance. The Geographical Journal 175(3): 208-220.

Braun B (2015) The 2013 antipode RGS-IBG lecture: New materialisms and neoliberal natures. Antipode 47(1), 1-14.

Braverman I (2015) Wild Life: The Institution of Nature. Stanford, CA: Stanford University Press.

Brenner, N., \& Theodore, N. (2002). Cities and the geographies of "actually existing neoliberalism". Antipode 34(3): 349-379.

Bresnihan P (2016) Transforming the Fisheries. Neoliberalism, Nature, \& the Commons. Lincoln, NE: University of Nebraska Press.

Bresnihan P (2017) The (slow) tragedy of improvement: Neoliberalism, fisheries management \& the institutional commons. World Development. Epub ahead of print 6 November 2017. DOI: 10.1016/ j.worlddev.2017.09.017.

Brosius JP, Tsing AL and Zerner C. (eds) (2005) Representing Communities: Histories and Politics of Community-Based Natural Resource Management. London: Altamira Press.

Burchell G (1996) Liberal government and techniques of the self. In: Barry A, Osborne T and Rose N (eds) Foucault and Political Reason. London: UCL Press, pp.19-36.

Commission for Environmental Cooperation (2009) Green paper on reform of the Common Fisheries Policy. COM 163 final, European Commission, Brussels.

Commission for Environmental Cooperation (2011a) CFP reform: the discard ban. European Commission, Brussels.

Commission for Environmental Cooperation (2011b) Fisheries: The EU 'zero tolerance' campaign against illegal fishing gets tougher. European Commission, Brussels.

Commission for Environmental Cooperation (2011c) Impact assessment of discard reducing policies. Draft final report. European Commission, Brussels.

Cooper M (2008) Life as Surplus: Biotechnology and Capitalism in the Neoliberal Era. Seattle, WA: University of Washington Press.

Coveney S (2013) Fisheries Council press conference. Available from: http://video.consilium.europa. eu/webcast.aspx?ticket=775-979-12874.

Dalla Costa M and Chilese M (2014) Our Mother Ocean: Enclosure, Commons, and the Global Fishermen's Movement. New York: Common Notions.

Damanaki M (2011b) The new Common Fisheries Policy: making things simpler. SPEECH/11/191. Available at: http://europa.eu/rapid/press-release_SPEECH-11-191_en.htm?locale $=$ en (accessed 21 September 2018).

Dardot P and Laval C (2013) The New Way of the World: On Neoliberal Society. London: Verso.

De Angelis, M. (2013). Does capital need a commons fix?. Ephemera 13(3): 603.

Dempsey J (2016) Enterprising Nature: Economics, Markets, and Finance in Global Biodiversity Politics. Chichester: John Wiley \& Sons.

Fletcher R (2017) Environmentality unbound: Multiple governmentalities in environmental politics. Geoforum 85: 311-315.

Foley P (2012) The political economy of Marine Stewardship Council certification: Processors and access in Newfoundland and Labrador's inshore shrimp industry. Journal of Agrarian Change 12(23): $436-457$. 
Foley P and Hébert K (2013) Alternative regimes of transnational environmental certification: Governance, marketization, and place in Alaska's salmon fisheries. Environment and Planning A 45(11): 2734-2751.

Foley P and Mather C (2016) Making space for community use rights: Insights from 'community economies' in Newfoundland and Labrador. Society \& Natural Resources 29(8): 965-980.

Foley P and McCay B (2014) Certifying the commons: Eco-certification, privatization, and collective action. Ecology and Society 19(2): 28.

Forsyth T and Johnson C (2014) Elinor Ostrom's legacy: Governing the commons, and the rational choice controversy. Development and Change 45(5): 1093-1110.

Foucault M (1991) Governmentality. In: Burchell G, Gordon C and Miller P (eds) The Foucault Effect: Studies in Governmentality. London: Harvester Wheatsheaf, pp.87-104.

Foucault M (1998) The will to knowledge: The history of sexuality vol. I. London: Penguin Books.

Foucault M (2004) Security, Territory, Population: Lectures at the College de France, 1977-1978. New York: Palgrave MacMillan.

Foucault M (2008) The Birth of Biopolitics: Lectures at the College de France, 1978-1979. New York: Palgrave MacMillan.

Gibson-Graham JK (2008) Diverse economies: Performative practices for other worlds. Progress in Human Geography 32(5): 613-632.

Gordon HS (1954) The economic theory of a common-property resource: the fishery. In Classic Papers in Natural Resource Economics (pp. 178-203). Palgrave Macmillan, London.

Gulbrandsen L (2009) The emergence and effectiveness of the Marine Stewardship Council. Marine Policy 33(4): 654-660.

Guthman J (2007) The Polanyian way? Voluntary food labels as neoliberal governance. Antipode 39(3): 456-478.

Heynen N and Robbins P (2005) The neoliberalization of nature: Governance, privatization, enclosure and valuation. Capitalism Nature Socialism 16(1): 5-8.

Jentoft S and McCay B (1996) From the bottom up: Participatory issues in fisheries management. Society and Natural resources 9: 237-250.

Joseph J (2013) Resilience as embedded neoliberalism: A governmentality approach. Resilience 1(1): $38-52$.

Kingfisher C and Maskovsky J (2008) Introduction: The limits of neoliberalism. Critical Anthropology 28(2): 115-126.

Klooster D (2010) Standardising sustainable development? The Forest Stewardship Council's plantation policy review process as neoliberal environmental governance. Geoforum 41: 117-129.

Larner W (2003) Neoliberalism? Environment and Planning D: Society and Space 21: 509-512.

Lave R (2018) Not so neo. In Bigger P and Dempsey J (eds) Reflecting on neoliberal natures: an exchange: The ins and outs of neoliberal natures. Environment and Planning E: Nature and Space. 1(1-2): 30-33.

Lemke T (2002) Foucault, governmentality, and critique. Rethinking Marxism 14: 49-64.

Lemke T (2011) Bio-Politics: An Advanced Introduction. New York: New York University Press.

Leonardi E (2017) For a critique of neoliberal green economy: A Foucauldian perspective on ecological crisis and biomimicry. Soft Power 5(1): 169-185.

Li TM (2002) Engaging simplifications: Community-based resource management, market processes and state agendas in upland Southeast Asia. World Development 30(2): 265-283.

Li TM (2007) The Will to Improve: Governmentality, Development, and the Practice of Politics. Durham, NC: Duke University Press.

Mansfield B (2004) Neoliberalism in the oceans: 'Rationalisation', property rights, and the commons question. Geoforum 35: 313-326.

Mansfield B (2007) Property, markets, and dispossession: The western Alaska community development quota as neoliberalism, social justice, both, and neither. Antipode 39(3): 479-499.

Mansfield B and Doyle M (2017) Nature: A conversation in three parts. Annals of the American Association of Geographers 107(1): 22-27. 
Marine Stewardship Council (2010) MSC responds to questions about Antarctic krill certification. Available at: http://www.msc.org/newsroom/news/msc-responds-to-questions-about-antarctickrill-certification (accessed 14 December 2017).

Marine Stewardship Council (2011) Get certified! A practical guide to the Marine Stewardship Council's fishery certification process. Available at: http://www.msc.org/documents/get-certified/ fisheries/MSC_Get-certified_FINAL_lowres.pdf (accessed 30 May 2015).

Mather C, Johnsen JP, Sonvisen S, et al. (2017) Introduction to the themed issue: Poststructural approaches to fisheries. Maritime Studies 16(1): 20.

McCay BJ and Acheson JM (Eds.) (1990) The question of the commons: The culture and ecology of communal resources. University of Arizona Press.

McCarthy $\mathbf{J}$ and Prudham S (2004) Neoliberal nature and the nature of neoliberalism. Geoforum 35(3): 275-283.

McCormack F (2017) Private Oceans: The Enclosure and Marketisation of the Seas. London: Pluto Press.

Nelson S (2015) Beyond the limits to growth: Ecology and the neoliberal counterrevolution. Antipode 47(2): 461-480.

Ostrom E (1990) Governing the Commons: The Evolution of Institutions for Collective Action. Cambridge: Cambridge University Press.

Ostrom E (2008) Governing the Commons: The Evolution of Institutions for Collective Action. 22nd ed. Cambridge: Cambridge University Press.

Pellizzoni L (2011) Governing through disorder: Neoliberal environmental governance and social theory. Global Environmental Change 21: 795-803.

Pennington M (2012) Elinor Ostrom, common-pool resources and the classical liberal tradition. In: Ostrom E, Chang C, Pennington M, et al. (eds) The Future of the Commons: Beyond Market Failure and Government Regulation. London: Institute of Economic Affairs.

Pinkerton E and Davis R (2015) Neoliberalism and the politics of enclosure in North American smallscale fisheries. Marine Policy 61: 303-312.

Ponte S and Cheyns E (2013) Voluntary standards, expert knowledge and the governance of sustainability networks. Global Networks 13(4): 459-477.

Povinelli E (2011) Economies of Abandonment: Social Belonging and Endurance in Late Liberalism. Durham, NC: Duke University Press.

Rabinow P (1996) Making PCR: A Story of Biotechnology. Chicago, IL: University of Chicago Press.

Rabinow P and Rose N (2006) Biopower today. Biosocieties 1: 195-217.

Read J (2009) A genealogy of Homo-economicus: Neoliberalism and the production of subjectivity. Foucault Studies 6: 25-36.

Reid J (2013) Interrogating the neoliberal biopolitics of the sustainable development-resilience nexus. International Political Sociology 7(4): 353-367.

Robertson MM (2006) The nature that capital can see: Science, state, and market in the commodification of ecosystem services. Environment and Planning D: Society and Space 24(3): 367-387.

Rose N and Miller P (1995) Political power beyond the state: Problematics of government. The British Journal of Sociology 43(2): 173-205.

Rutherford S (2007) Green governmentality: Insights and opportunities in the study of nature's rule. Progress in Human Geography, 31(3): 291-307.

Sissenwine M and Symes D (2007) Reflections on the Common Fisheries Policy: Report to the General Directorate for Fisheries and Maritime Affairs of the European Commission. Brussels: European Commission.

Smith J (2009) Interview with the author, Cork, 10 May.

St. Martin K (2007) The difference that class makes: Neoliberalisation and non-capitalism in the fishing industry of New England. Antipode 39: 528-549. 
Sullivan S (2017) What's ontology got to do with it? On nature and knowledge in a political ecology of the 'green economy'. Journal of Political Ecology 24(1):217-242.

Taylan F (2013) Environmental interventionism: A neoliberal strategy. Raisons Politiques 52: 77-87.

Tully O (2004) Integration of biology and management in lobster fisheries. In: Tully O (ed.) The Biology and Management of Clawed Lobsters (Homarus gammarus L.) in Europe. Dún Laoghaire: Bord Iaschaigh Mhara.

Vardy M and Smith M (2017) Resilience. Environmental Humanities 9(1): 175-179. 